\title{
Social Role OF the UnIted Nations in ReSOlUtion OF INTERNATIONAL CONFLICTS
}

\section{Abstract:}

The matter of role and influence of the United Nations in resolution of international conflicts is decisive because they demonstrate their legal presence at the national as well as international level. Throughout the paper, the authors insist on determination of resolution of international conflicts pursuant to Chapter VII of the Charter of the United Nations. The basic hypothesis of the paper has been established on the premise by studying relevant provisions of 1945 Charter of the United Nations, 1949 Geneva Conventions and two additional protocols of 1977, United Nations resolutions, international treaties and international customary rules of war, it is possible to accurately determine the role, character and significance of the United Nations Security Council and the United Nations General Assembly in resolution of international conflicts. Furthermore, it is of interest to note that decisive significance for confirmation of the hypothesis lies with the objective image of the United Nations presented through mechanisms of the international law for resolution of armed conflicts. Furthermore, throughout the entire paper, the authors present international conflict resolution instruments as well as applicable legal consequences of effective resolution of the same, and ultimately, in the concluding considerations, they confirm that actions regarding resolution of armed conflicts are current, essential and timely.

\section{Keywords:}

international conflicts; United Nations; Charter of the United Nations; United Nations Security Council; United Nations General Assembly

\section{Author's data:}

1 assistant professor, University of Vitez, Poslovni centar 96-2, Vitez, mirza.causevic@unvi.edu.ba

${ }^{2}$ college professor, Poytechnic in Požega, Vukovarska 17, Požega, mvitez@vup.hr 


\section{Introduction}

Since international law entities represent an important segment in sustainability and maintenance of global, regional, and national legal and political order, it is significant to determine the manner in which legal structures are defined and perceived in resolution of international conflicts. Accordingly, a separate central analytical and experimental section of this paper is dedicated to the primary role of the United Nations as an entity dealing with resolution of international conflicts by force.

Accordingly, research problem in this paper is oriented at insufficiently scientifically founded insights into international theoretical, practical and legal resolution of armed conflicts by the United Nations. Positions and proposals will be used for the purpose of elaboration of modalities and methods applied to go beyond status quo of the researched matter itself.

Therefore, a race against time to find a peaceful resolution as quickly as possible led to defining of the primary subject of research entailing a set of legal rules determining the role of the United Nations in resolution of international conflicts and relevant characteristics of the notion of an international conflict and the purpose of the United Nations in resolution of the same will be simultaneously researched in detail. The subject of research also pertains to emphasising general and special principles of the international law and a certain emphasis is also placed on the notion of justice itself as an absolute virtue and the basic awareness module from the aspect of quest for resolution for an international conflict. Bodies of the United Nations (General Assembly and Security Councill) whose competence is fully dedicated to overcoming international conflicts (wars) are reviewed in the context 0 the paper itself and their positions will be objectively presented through the primary research results alone.

Adhering to permanence of legal axioms in fixing of a methodological framework in this article, the research concerns the United Nations and, i.e. nature and role of this international legal entity in resolution of international conflicts.

A basic hypothesis was methodologically established in accordance with the problem, subjects and objects of research. By studying relevant provisions of 1945 Charter of the United Nations, 1949 Geneva Conventions and two additional protocols of 1977, United Nations resolutions, international treaties and international customary rules of war, it is possible to accurately determine the role, character and significance of the United Nations Security Council and the United Nations General Assembly in resolution of international conflicts.

For the purpose of demonstration of the objectives of the research, it is necessary to investigate and scientifically confirm all relevant characteristics, nature and role of the most significant resolutions, recommendations, conventions and other legal acts of the United Nations in resolution of armed conflicts. All this will also facilitate verification of the fundamental hypothesis itself through the most significant characteristics of the international law, justice and equity allowing a systematic presentation of the results of the research.

Research of the relevant topic would be futile without application of scientific methodology of law. Accordingly, three main legal methods are applied: dogmatic, normative and sociological method. Notions of international law entities, justice and equity as they are will be interpreted through application of the dogmatic method within the framework of formation of results of the research, i.e. resolution of international conflicts by the United

\section{VALLS International Journal - VALLIS AUREA • Volume 5 • Number 2 • Croatia, December 2019 AUREA


Nations will be interpreted through applicable international legal acts. Interpretation of international legal documents of the United Nations in the course of resolution of international conflicts through use of force will facilitate verification of the fundamental hypothesis. Application of the normative method in this paper, shall allow determination of measures of impact of international legal acts of the United Nations on other legal acts (act of influence) initially reflected in definition and interpretation of use of the normative system for resolution of armed conflicts. The normative method is also used to identify sources of law (in this case, sources of international law), determine relevant legal rules (international law rules enshrined in the Charter of the United Nations Chapter VII: Action with respect to Threats to the Peace, Breaches of the Peace, and Acts of Aggression] as well as their structure which also regulate the subject of research in this paper. Application of the sociological method in this paper facilitates insight into the international law entity in a wider sense entailing examination of relationship of legal norms of international legal acts and other phenomena such as social, economic, sociological, political, philosophical and other also monitoring the events before, during and after international conflicts. This paper elaborates on the international law, justice and equity in relation to armed conflicts and their timely applicability on the same.

The article consists of four sections: (1) Introduction; (2) International conflicts; (3) Role of the United Nations in resolution of international conflicts; (4) Conclusion.

\section{International conflicts}

Since 1945, the world has only seen 26 days without any wars. Frequency of wars in theworld is increasing since 1945 - 3 wars, since 1955 - 15 wars, since 1975 - 21 wars, since 1985 - 33 wars, since 1995 - 43 wars, and since 2005 until today - 65 wars which continue to multiply on the daily basis. [1]

On the basis of the above indisputable facts, there is a clear conclusion that international conflicts are not humane as such even though they are sets of rules, armed (international) measures and requirements used to overcome an adversary and impose one's own (victor's) will. By interpreting history of ancient peoples (India, Rome, Greece etc.) it is apparent that military commanders were restricted from inhumane actions and use of excessive force, also pointing at application of ius ad bellum (right to war) as a significant characteristic of primordial nature of state "sovereignty". Therefore international conflicts have never been interpreted as wild use of uncontrolled force and lack of ability of belligerents to use that force freely and without any restriction. [2]

once, but also in present time, it has been specifically pointed out that ethical considerations, humanity, law and justice were decisive and crucial factors in restricting excessive force in international conflicts. Accordingly, it is necessary to remind one of Hugo Grotius who wrote in De jure belli ac pacis (On the Law of War and Peace) that the rulers and commanders avoided use of "secret" weapons in international conflicts because they might become victims just like regular warriors if the opponent were to use the same. Namely, fear of commensurate retaliation has been a reliable means of prevention of violations of rules of warfare. [3]

Professor Vladimir Auro Degan considers the notion of an international conflict "wider than the notion of war, because some of those conflicts do not always lead to recognised state of war by all its participating states". [4] Accordingly, professor Zijad Hasić interprets international conflicts as a "set of violent 
activities whereby a state wishes to impose its own will on another state and wishes to achieve that aim using any means". [5]

Characteristics of international conflicts imply two or more belligerents, rules of war - codified law of war - respect for international humanitarian law (Geneva and Hague law) as well as general customary rules of war. Accordingly, it may be concluded that the characteristics of international conflicts are represented through an armed conflict between states and such an international conflict represents a set of coercive measures used by each warring party to submit the other to its will. [6] [7]

Matters of war or peace are equally included in areas of international politics as in the matters of conflict as such. War may simply be defined as the most ubiquitous means of conflict among political groups with the primary objective of destroying the enemy or forcing it to accept directly dictated terms of peace. Ancient Greeks had two words denoting war, specifically stasis and polemos. stasis only denoted wars among Greeks while polemos was war against barbarians. Until the French Revolution, war was a "roval sport" of rulers in which professional armies participated. [8] Therefore the very notion that diplomacy strives to avoid wars was swaved and brought into question from an allegedly realistic basis because diplomacy of Louis XVI, Napoleon or Bismarck truly invested more efforts into preparations for a war instead of avoiding one. [9]

However, modern international humanitarian law is primarily enshrined in four 1949 Geneva Conventions and two 1977 protocols and it categorises all international conflicts as: 1] International armed conflicts, 2] Non- international armed conflicts, and 3) Internal disturbances and tensions. [9] The international armed conflicts mean resorting to armed force among international law entities [states]. Therefore, under Article 1(4) of the additional 1977 Protocol I relating to the Protection of Victims of International Armed Conflicts, the following are deemed international armed conflicts: "conflicts in which peoples are fighting against colonial domination and alien occupation and against racist regimes in the exercise of their right of selfdetermination, as enshrined in the charter of the United Nations and the Declaration on Principles of International Law concerning Friendly Relations and Co-operation among States in accordance with the Charter of the United Nations" [10] An international armed conflict is interpreted as an armed conflict formulated through long lasting armed violence among authorities and organised armed groups or among non-governmental armed groups within a state. Accordingly, under the additional Protocol II relating to the Protection of Victims of Non-International Armed Conflicts a non-international armed conflict represents: an armed conflict "between its armed forces and dissident armed forces or other organized armed groups which, under responsible command, exercise such control over a part of its territory as to enable them to carry out sustained and concerted military operations and to implement this Protocol." [11] Internal disturbances and tensions (riots, isolated and sporadic acts of violence) are not armed conflicts, but they imply means to incite conflicts.

A very important segment for conduct of war activities is the Lieber Code which took effect in April 1863and it is significant because it represents 
the first attempt to codify existing laws and customs of war, however the code did not have the status of an international treaty since it was only intended for Union soldiers in the American Civil War. [12] It is also necessary to mention the Martens Clause prescribing that primarily rules prescribed under the 1907 Fourth Hague Convention respecting the Laws and Customs of War on Land and other conventions shall be applied in armed conflicts and if there are no such rules, the "principles of the law of nations, as they result from the usages established among civilized peoples" shall apply and if there are no such rules, belligerents must apply principles of international law arising "from the laws of humanity, and the dictates of the public conscience." [13]

In order to humanise war, alleviate and improve position of direct participants in wars, rules of war have been systematised and codified and became popularly known as the law of Geneva and law of the Hague. The law of the Hague determines rights and obligations of belligerents during hostilities and restricts methods of inflicting losses on the enemy. It consists of conventions adopted at 1899 and 1907 Hague Peace Conferences concerning the method of warfare. The law of Geneva concerns protection of armed force members who do not actively participate in hostilities and mainly pertains to rules of humanity embodying the principle of humanity. [13]

\section{Role of the United Nations in resolution of international conflicts}

International [or intergovernmental] organisations are important international law entities whose reach and authority are related to multiple states and they may posses own legal personality or they may be recognised as being entities of the international-law. The most important international organisation are the United Nations established with the aim of promotion of international cooperation as well as preservation of world order, peace and prosperity.

Notion, establishment and objectives of the United Nations

Outbreak of the World War II following invasion of Poland by the Nazi Germany on 1 September 1939 Ied to the greatest failure of the League of Nations. Regardless of this failure, the very idea of maintenance of international peace through an universal international organisation persisted nonetheless. In order to avoid experience of nonparticipation of the United States of America in the League of Nations, Article 110(3) of the Charter of the United Nations foresaw it coming into effect only after deposit of ratifications by all five permanent members of the future Security Council (China, France, Soviet Union [Russia], the United kingdom, and the USA] and majority of its other signatory states. of course, this condition was met on 24 October 1945 when a new international organisation of a universal character has been created. Directly afterwards, the charter of the United Nations has also been ratified by all remaining signatory states. [14]

Therefore, it may be state that the United Nations are a universal international organisation for maintenance of peace and security in the world, development of good relations among neighbouring states, development of economic cooperation, spreading of tolerance and promoting respect for human rights and fundamental 
freedoms of humans and citizens, and the above aims are formulated in Article 1 of the 1945 Charter of the United Nations (hereinafter: the Charter) [15]. Accordingly, it may be clearly concluded that the United Nations have their own legal personality, separate from Member states and most constitutional acts of international organisations recognise their ability to express the legal personality in the territory of the Member states. [16]

\section{Membership and principles of the United Nations}

Admission to membership of the United Nations involves two elements: (a) compliance with material conditions for membership in the Organisation under Article 4(1) of the charter and (b) appropriate admission procedure. [17] Members of the United Nations may be classified as founding states and subsequently admitted Members. The founding states (original Members) are states which took part in the founding Conference in San Francisco in 1945, while subsequently admitted Members are those states which went through the determined admission procedure after the Organisation has been established. [17] The United Nations Member admission procedure takes place in three stages. The first stage entails submission of an admission request by the state wishing to become a Member of the Organisation. The request should contain a declaration of preparedness of the applicant to accept the obligations contained in the charter. In the second stage, the request is examined by the United Nations Security Council, specifically material compliance with the conditions for admission of candidate states within the meaning of Article 4[1] of the Charter. Therefore, the role of the Security Council is to provide initiative and control. The third and the final stage entails deciding on admission by two-thirds majority of those present and voting at the General Assembly of the United Nations. [17]

It is necessary to comply with the principles enshrined in Article 2 of the charter to allow the United Nations to achieve the objectives defined in Article 1 of the Charter. Precisely the above principles create instrumental support needed to achieve the objectives of the United Nations.

\section{Bodies of the United Nations for resolution of international conflicts}

The Charter itself specifies the main bodies of the United Nations, specifically: General Assembly, Security Council, Economic and Social Council, Trusteeship Council, International Court of Justice, United Nations Secretariat. [15] Aiming to achieve better, clearer and more credible elaboration of the role of the bodies of the United Nations for resolution of international conflicts, the significance, role and character of the United Nations General Assembly and of the United Nations Security Council will be particularly set apart. Furthermore it is important to emphasise that the above bodies of the United Nations are decisive for timely and successful resolution of international conflicts and this would be practically possible without the United Nations General Assembly and the United Nations Security Council. The General Assembly of the United Nations is the body where all Members of this international organisation are represented. Each Member has one vote in this body. It meets each year in regular sessions and special sessions are 
held if necessary. The General Assembly works in plenary sessions and committees and agenda matters are normally considered in detail by appropriate committees, but the General Assembly always renders its decisions in plenary sessions. International legal acts of the General Assembly are resolutions and they are not legally binding, but they may be evidence of creation of an international custom. [18]

Under Article 11(1) and (2) of the Charter, the General Assembly may the general principles of cooperation in the maintenance of international peace and security, including the principles governing disarmament and the regulation of armaments, and may make recommendations with regard to such principles to the Members or to the Security Council. Accordingly the General Assembly may discuss all matters of maintenance of international peace and security brought before it by and Member of the United Nations or the Security Council or a state which is not a Member of the United Nations. Also, under Article 13(1) of the Charter, the General Assembly gives recommendations aimed at promoting international co-operation in the political field and encouraging the progressive development of international law and its codification. It is necessary to point out that the General Assembly considers and approves the budget of the Organisation and considers and approves all financial and budgetary arrangements.

In 1950, during the Korean crisis, the General Assembly adopted resolution 377 (V) - "Uniting for Peace". On the basis of this resolution, the General Assembly had the opportunity to recommend collective measures in case of aggression and severe violations of the international law only once and afterwards it constantly referenced the aforementioned resolution when establishing United Nations peace operations and convening special sessions, but it did not use it as the basis for collective measures. [19]

The United Nations Security Council consists of 15 members. The permanent members of the Security Council are: China, France, Russia, the United kingdom, and the United states of America. The General Assembly of the United Nations elects ten other Members of the United Nations to be nonpermanent members of the Security Council, due regard being specially paid, in the first instance to the contribution of Members of the United Nations to the maintenance of international peace and security and to the other purposes of the Organisation, and also to geographical distribution and representation of states in compliance with Article 23(1) of the Charter. Under Article 23(2) and (3) of the Charter, the nonpermanent members of the Council are elected for a term of two years and in the first election of the non-permanent members after the increase of the membership of the Security Council from eleven to fifteen, two of the four additional members shall be chosen for a term of one vear. A retiring member is not eligible for immediate re-election. Each member of the Security Council has one representative.

The Security Council is devised as an operative body. For it to act rapidly and successfully, it is organised in a manner allowing it to discharge its duties continuously which means that each member of the council has its permanent representative at the seat of the organisation. [20] The Security Council is entrusted with competence in two most important sectors of activities of this 
Organisation, specifically: (1) maintenance of peace and security and (2) an electoral function which indispensable for functioning of the entire mechanism of the United Nations. The Charter itself foresees two mechanisms for maintenance of peace and security in the world: (1) peaceful resolution of disputes and (2) taking collective measures regardless if they are preventive or coercive. [20] Competence [20] of the Security Council may be divided to the primary and secondary competence. The primary competences consists of preservation of international peace and security under Chapters VI and VII of the Charter. Unlike the primary competence, the secondary competence of the Security Council entails functions not directly related to maintenance of international peace and security (e.g. recommendation on election of the General Secretary of the United Nations].

The General Assembly of the United Nations has general authority to consider, discuss and interpret matters initially concerning peace and security, but it is also additionally entitled to resolve individual cases by applying the principle of subsidiarity to the Security Council. Therefore, it may be clearly concluded that the United Nations Security Council is the most important body of this international organisation and its paralysis means paralysis of the entire Organisation. The 1950 "Uniting for Peace" allows the General Assembly to convene an emergency special session within 24 hours upon a request of the majority of Organisation Members or a procedural resolution of the Security Council which is not subject to the right of veto at the same time if the Security Council is unable llack of unanimity of the permanent members) in pursuit of preservation, defence and maintenance of peace and security. [21] In essence, the above resolution made it easier for the General Assembly - if the Security Council is paralysed - to take over finding of a solution for individual matters and recommend solutions depending on voluntary support of the Members. However, the authority thereby received by the General Assembly have not even remotely approached those foreseen for the security Council. [21]

The main and key responsibility of the Security Council is maintenance of international peace and security (Article 24(1) of the Charter). When it determines that there is a threat to the peace, breach of the peace, or act of aggression in a part of the world (Chapter VII of the Charter), it may in addition to recommendations, also render decisions binding for all Member states. In addition to the primary competences, the security Council recommends the General Assembly admission, suspension, and expulsion of states from membership in the United Nations and cooperates with the General Assembly in a parallel procedure of election of judges of the International Court of Justice in the Hague. [4]

In accordance with the above, it may be concluded that the competences, nature, and role of the General Assembly and the Security Council are intertwined and that both bodies primarily and through subsidiarity affect each other.

\section{United Nations Agenda for Peace}

The overarching, main and key objective of the United Nations is preservation of world peace and security. Upon conclusion of the Cold War and fall of the Iron Curtain it appeared that, somewhat belatedly, golden age of functioning of the United 
Nations began. The Agenda for Peace, one of the most important present-day peace strategies originated in that period. Such a concept of peace axioms for preservation of world peace was created in 1992 by Boutros Boutros-Ghali, former General Secretary of the United Nations. [22]

Word "peace" is used in the Charter in multiple places and in several ways, but the term is never clearly defined. In the system of "classical" international law of late 19th and early 20th centuries, "peace" was understood very simply as mere absence of war. United Nations' understanding of the word "peace" surpasses this narrow definition and concerns a global and dynamic process whereby social justice, respect and enjoyment of human rights and friendly relations between all countries should be achieved. Therefore the charter does not obligate all the Member states only to departure from use of forceand violence in pursuit of their goals, but also calls upon resolving conflicts peacefully and developing cooperation in all fields. [22]

Typology of peaceful political resolution of conflicts and instruments used to resolve international conflicts is basically transferred into the Agenda for Peace in 1994 by the then General Secretary of the un Boutros Boutros-chali in four stages: (1) prevention of international conflicts, (2) peacemaking, (3) peace-keeping, and (4) postconflict peace-building.

Prevention of international conflicts

The main objective of preventive diplomacy is preventing violent conflicts. In order to achieve and implement the above objective, the following means of prevention are used in a timely manner: diplomacy, trust building measures, early warning system, demilitarised zones, preventive deployment of United Nations troops.

Iwo terms within the first stage of the Agenda for Peace having the greatest importance are preventive diplomacy and preventive deployments. Preventive diplomacy means use of diplomatic assets with the aim of preventing occurrence of conflicts between two parties, preventing escalation of existing conflicts and, if there is still an open conflict, to limitit. Preventive deployments entail deployment of troops tasked with prevention of outbreak of a conflict. A preventive deployment of United Nations troops within a state may only occur with prior consent of government or all parties involved in the conflict. The same procedure also applies if a state feels it is threatened by another and if it submits a request for preventive deployment of $u N$ troops on its side of the border.

\section{Peacemaking}

The main objective of peacemaking is timely bringing of the conflicting parties to negotiating table and achieving peace agreements. In order to realise and achieve the aforementioned objective, the following legal means and means of coercion are used in a timely manner: intermediation, legal decision, International Court of Justice, nonviolent sanctions, peacemaking by United Nations troops, and military force as the last resort for successful peacemaking.

Peacemaking is a process taking place until conclusion of a peace treaty or a ceasefire agreement and it includes activities aimed at bringing the conflicting parties to a negotiating table specifically using the non-violent means described in Chapter VI of the charter of the United Nations. 
Peace-keeping

A direct objective of peace-keeping is stabilisation of situation and monitoring of compliance with agreements by the parties previously in conflict. In order to achieve the aforementioned objective, the following coercive means of the international law are used in a timely fashion: monitoring missions, United Nations peace-keeping troops, buffer zones, providing humanitarian aid. Therefore these means may be succinctly labelled "comprehensive conflict management".

Peace-keeping assumes presence of the institution of the United Nations at the site, with prior consent of the conflicting parties. The United Nations have at their disposal lightly armed soldiers, observers, and police officers and all of them are tasked with ensuring and implementing ceasefires and maintaining achieved peace agreements. Peace-keeping is a technique also allowing protection against outbreak of conflicts and, on the other hand, strong enforcement of peace. [22]

\section{Post-conflict peace-building}

Key objective of post-conflict peace-building is restoring the legal order and government system of countries directly affected by devastating effects of war activities by belligerents. In order to achieve the aforementioned objective, the following postconflict peace-building means of the international law are used in a timely manner: disarmament, mine clearance, return and integration of refugees, assistance in restoration of state order [e.g. elections, government institutions], joint projects of recent adversaries. [22]
Post-conflict peace-building represents restoration and/or improvement of government structures once the conflict is successfully ended and it proved successful in determination and consolidation of peace and prevention of reviving of old conflicts. This includes: demobilisation of former warriors, their disarmament and reintegration in the civil society or building an administrative, cultural, social and legal system in compliance with the principles of a legal democratic state.

\section{Conclusion}

Waging of numerous wars represents a hard and difficult reality of the global world order. Wars are waged for a variety of reasons, justified or otherwise, but despite this, the international humanitarian law strives to humanise wars themselves and war actions through the 1949 Geneva Conventions and the 1977 Additional Protocols.

In the course of historic development of the United Nations, a special place belongs to conventions adopted in pursuit of peaceful (1899 and 1907 Hague Conventions for the Pacific Settlement of International Disputes) and coercive resolution of armed conflicts which accordingly primarily strive to build a modern peaceful dispute resolution system. Methods of peaceful resolution of disputes cdiplomatic means, institutionalised means and means leading to a binding judgment or award] represent an original and primary pointer towards the fastest and most flexible peaceful resolution of armed conflicts under patronage of the United Nations. 
Why have some agreements been successfully implemented while the others failed? Why is it impossible to apply in the contemporary world those axioms advocated by Thomas Woodrow Wilson and Thomas Jefferson? What are the determinants of success, appropriate strategies, priority objectives and the very link between shortterm application and long-term peace-building? Answers to these and other numerous questions depend on quality and quantity of preventive action by entities, mechanisms and other factors involved in preservation of international peace and if the determined objectives cannot be achieved through those means, the second step is timely application of coercive means by the United Nations.

Accordingly, in conclusion of this research enterprise, it is important to emphasised that the role of the United Nations is indispensable in resolution of armed conflicts, but it is very important to act on time because it is easier to put out a flicker than raging fire of large proportions. Process of prevention and early resolution of international conflicts requires ongoing, intensive, purposeful, selfless efforts and affirmation of heads of state, foreign ministers, prime ministers, international law entities, universal and regional international organisations of all ranks and also professors and legal professionals active in the field of international law as well as relevant diplomatic missions, states and regions at micro, macro and global levels. Positions and proposals directly and indirectly linked to the topic of the paper are elaborated through the following aspects:

- Global interest of maintenance of peace and security should have supranational primary character while interests of great powers and permanent members of the Security Council (in this case limitation of the veto power] which would possibly depart from the above objective represent the secondary interest. The secondary interests should never bring into question the main objectives and principles of the United Nations. If such policy of the United Nations fails to deliver the desired result, they should embark on pursuit of their objectives through coercive means la harsher policy permissible under the charter);

- Better coordination of bodies of the United Nations for resolution of international conflicts, exclusively the General Assembly and the Security Council (action and reaction body) and not permitting belligerents to disobey and violate acts of international law (resolutions, conventions, agreements etc.] and coercion of the same to respect legal acts of the international law;

- Greater involvement and dedication of all participants in the Agenda for Peace of the United Nations as well as execution and high-quality defining of the current situation in an international or a non-international armed conflict aiming to achieve faster and more effective restoration of peace and general security.

\section{References}

[1] Friedenspädagogik, Available at: http://www.dadalos.org/frieden_hr/grundkurs_2 /krieg.htm, Accessed: 12.09.2019.

[2] Perazič, G. Đ. (1966). Međunarodno ratno pravo (International Law of War], Kultura Beograd, Belgrade

[3] Grotius, H. [2018). On the Law of War and Peace, (De jure belli ad pacis), Jazzy bee Verlag, Altenmiunster, Germany, ISBN 9783849687786 
[4] Degan, V. Ө. (2000). Međunarodno pravo (International Law), Rijeka Law Faculty, Rijeka, ISBN 953-6597-13-6

[5] Hasić, z. [2005]. Međunarodno humanitarno pravo (International Humanitarian Law), The Council of Congress of Bosniak Intellectuals, Sarajevo, ISBN 9958-47-098-5

[6] Radojković, M. M. (1947). Rat i međuunarodno pravo (War and International Law), Committee for Textbooks of the Professional Association of Law Students, Belgrade

[7] Andrassy, J. [1961]. Medunarodno pravo (International Law), Školska knjiga, Zagreb

[8] Tadić, Lj. (1988). Nauka o politici (Science of Politics], Rad, Belgrade, ISBN 86-09-00105-9

[9] Fridrih, K. J. [2005). Konstitucionalna demokratija - teorija i praksa u Evropi i Americi Constitutional Democracy - Theory and Practice in Europe and America], CID Podgorica, Podgorica, ISBN 86-495-0224-5

[10] Additional Protocol to the Geneva Conventions of 12 August 1949 relating to the Protection of Victims of International Armed Conflicts (Protocol I], Official Journal of the SFR Yugoslavia International Treaties, no. 16/78

[11] Additional Protocol to the Geneva Conventions of 12 August 1949 relating to the Protection of Victims of Non-International Armed Conflicts (Protocol II), Official Journal of the SFR Yugoslavia - International Treaties, no. 16/78

[12] FPN - Centre for International Humanitarian Law and International Organizations, http://mhp.fpn.bg.ac.rs/pitanja_odgovori/pitanj a_odgovori_3.html, Accessed: 18.09.2019.

[13] Škrbič, A. The Sources Law of Armed Conflict Izvori prava oružanih sukoba, International Law of War Crimes, Available at: http://www.orbus.be/justitia/izvori_prava_oruža nih_sukoba.htm, Accessed: 18.09.2019.

[14] Bartoš, M. (1956). Međunarodno javno pravo, II knjiga - oblasti i organi za međunarodno predstavljanje (International Public Law, Volume II - International Representation Bodies and Regions, Kultura Beograd, Belgrade

[15] Charter of the United Nations, Available at: http://www.mvep.hr/CustomPages/Static/HRV/Fil es/ugovori/povelja_un_hr.pdf, $\quad$ Accessed: 19.09.2019.

[16] Andrassy, J.; Bakotić, B. \& Vukas, B. [1998]. Međunarodno pravo I (International Law II), školska knjiga Zagreb, Zagreb, ISBN 953-0-30409-9

[17] Kreća, M. (2009). Međunarodno javno pravo I (International Public Law I), University of Belgrade, Faculty of Law, Belgrade, ISBN 978-86-519-0165-5

[18] Brownlie, I. [2003). Principles of Public International Law, Cambridge Press, Cambridge, ISBN 978-0199260713

[19] Dimitrijevič, V.; Račić, 0.; Đerič, V.; Papič, I.; Petrovic, V. \& Obradovic, S. [2007). Osnovi medunarodnog javnog prava (Basics of the International Public Law], 2nd edition, Dosije, Belgrade, ISBN 978-86-7738-083-0

[20] Avramov, S.; Kreća, M. [2009). Međunarodno javno pravo (International Public Law), University of Belgrade, Faculty of Law, Belgrade, ISBN 978-86-5190312-3

[21] Račić, 0. \& Dimitrijijević, V. (1988). Međunarodne organizacije (International Organisations), Savremena administracija, Belgrade, ISBN 86-387$0062-8$

[22] Müller, R. (2000). Friedenspolitik der Vereinten Nationen, Available at: http://Www.dadalosd.org/frieden/grundkurs_2/agenda.htm, Accessed: 24.09.2019. 